\title{
Technic and Mystics of Tukang Wangunan in Sundanese Traditional Houses in Indonesia (Case Study: Baduy Tribe Community-Banten)
}

\author{
Nuryanto ${ }^{1}$, Ngakan Ketut Acwin Dwijendra ${ }^{2, *}$, Syamsul Alam Paturusi ${ }^{2}$, I Made Adhika ${ }^{2}$ \\ ${ }^{1}$ Student of Doctoral Program Engineering Science, Faculty of Engineering, Udayana University-Bali, Indonesia \\ ${ }^{2}$ Department of Architecture, Faculty of Engineering, Udayana University-Bali, Indonesia
}

Received January 3, 2021; Revised March 13, 2021; Accepted March 28, 2021

\begin{abstract}
Cite This Paper in the following Citation Styles
(a): [1] Nuryanto, Ngakan Ketut Acwin Dwijendra, Syamsul Alam Paturusi, I Made Adhika, "Technic and Mystics of Tukang Wangunan in Sundanese Traditional Houses in Indonesia (Case Study: Baduy Tribe Community-Banten), "Civil Engineering and Architecture, Vol. 9, No. 2, pp. 533-544, 2021. DOI: 10.13189/cea.2021.090226.
\end{abstract}

(b): Nuryanto, Ngakan Ketut Acwin Dwijendra, Syamsul Alam Paturusi, I Made Adhika (2021). Technic and Mystics of Tukang Wangunan in Sundanese Traditional Houses in Indonesia (Case Study: Baduy Tribe Community-Banten). Civil Engineering and Architecture, 9(2), 533-544. DOI: 10.13189/cea.2021.090226.

Copyright $\bigcirc 2021$ by authors, all rights reserved. Authors agree that this article remains permanently open access under the terms of the Creative Commons Attribution License 4.0 International License

\begin{abstract}
Modern Sundanese society, especially in the Provinces of West Java and Banten, Indonesia considers technique and mysticism two things that are impossible to meet, because the technique is rational while mysticism is irrational. This assumption is different from traditional societies that view technique and mysticism as being reconciled, one of which is in the process of building a house. This is the background of the research to reveal how technique and mysticism can meet and unite by the tukang wangunan (craftsman). The Baduy community in Lebak Regency, Banten Province, Indonesia was chosen as the research location, covering the Baduy Panamping Village. Baduy is a prototype of Sundanese traditional society that has existed for hundreds of years. This study uses a descriptive qualitative method with an ethnographic approach. The results showed that: (1) The Baduy community views that mystical elements occupy a higher position than techniques, because of their relationship with Karuhun (ancestors); (2) In the technical element, there is a core of strength as the knot point in the form of jangjawokan (incantations) which is always read by the tukang wangunan, so that it sticks firmly to every dimension of the material; (3) The meeting point between technique and mysticism lies in the belief system of the Baduy community, namely Sunda Wiwitan, which gave birth to three cosmological views: Buana Nyungcung, Buana Panca Tengah, and Buana Larang. Tukang
\end{abstract}

wangunan gets instructions from their ancestors through tirakat (special ritual), harewos (magical whispers), and impian (dreams) about how to bring together technical and mystical elements.

Keywords Technical, Mystical, Tukang Wangunan,Imah Panggung, Sunda Wiwitan

\section{Introduction}

Imah panggung (stilt house) is a form of the traditional Sundanese house in Baduy Village. It is hundreds of years old as a manifestation of the traditions and culture of its people. Likewise in various other areas scattered throughout Indonesia, such as joglo in Java, tongkonan in Toraja, griya in Bali, gadang in Padang, honai in Papua, and others. A traditional house is a form of community culture which Koentjaraningrat [1] calls artefak (artifacts). Adimihardja [2] states that traditional houses are artifacts made by certain communities that are full of values and meanings, built on ancestral rules. Paturusi [3] argues, traditional houses as architectural works when viewed from a tourism perspective are seen as man-made features that can be used as attractions. Dwijendra [4] explains the importance of understanding traditional house architecture 
as a manifestation of local traditional and cultural values that are full of symbolic and philosophical meanings. Adhika and Dwijendra [5] [27][28][31] emphasized that the main principle of traditional houses is obedience to customary rules so that beautiful harmonization can be established. Meanwhile, Nuryanto [6][29][32] states that traditional houses are seen as a manifestation of two local cultures that are mutually binding between the concrete (ragawi) and the abstract (tanragawi).

Traditional societies with strong ancestral traditions built houses with sharp instincts, symbolic meanings, cosmological values, philosophies, and even mystical approaches [26][30][33]. Generally, modern society prioritizes logic (technique or technology), while the mysticism is considered superstition. Traditional society uses both, namely technique and mystique combined into one. These two differences become very unique and interesting to, so that it raises the question: "why can the technical and mystical meet and unite?". This question will be sought and the answer will be found in traditional communities in Baduy village. Thus, this research can reveal how the combination of technique and mystique by the tukang wangunan can produce harmonious architectural works of imah panggung. In this case, harmony means being able to combine technical and mystical elements in noble work. Sundanese traditional architecture is one of the noble works produced by the skilled hands of tukang wangunan.

\section{Material and Methods}

The method used in this research is descriptive-qualitative, by observing the artifacts or physical remains of the architecture. To help researchers collect data in the field in strengthening their qualitative descriptive arguments, an ethnographic approach is needed. The ethnographic approach is often referred to as field research [7] or participant observation [8]. The scheme of the observation process was adapted from Spradley [9] with three steps: descriptive observation, focused observation, and selective observation. Research was conducted by observing physical traces, in three ways: product use, adaptation for use, display self and public messages [10].

\section{Research Result}

This research specifically reveals the relationship between technique and mystique so that the tukang wangunan in Baduy village can meet and integrate it. In the view of the tukang wangunan, the technique is illustrated as a cangkang (shell or wrap), while mysticism is as eusi (spirit or soul). According to them, the cangkang without eusi will be useless, will be weak, brittle, or defenseless (teu walakaya). A house built without being based on mystical power will be weak, even if it uses great and strong building techniques. The mystical power is believed by the tukang wangunan to come from their ancestors (karuhun), obtained through tirakat, harewos, impian and semadi (meditation or occult whispers). Honoring their ancestors is proof of their loyalty to tradition. The ritual practices that are carried out in every house building as a manifestation of their traditional values.

\section{Baduy Panamping village}

The research location in Baduy Panamping village, Kanekes Village, Leuwidamar District, Lebak Regency, Banten Province-Indonesia. The research location can be seen on the map (fig. 1) below.

There are three groups of Baduy people, namely Tangtu, Panamping, and Dangka. Tangtu is the core of Baduy with the highest degree (sacred), while Panamping and Dangka are the opposite (profane). The research location in Baduy Panamping village is a part of the traditional Baduy community. 


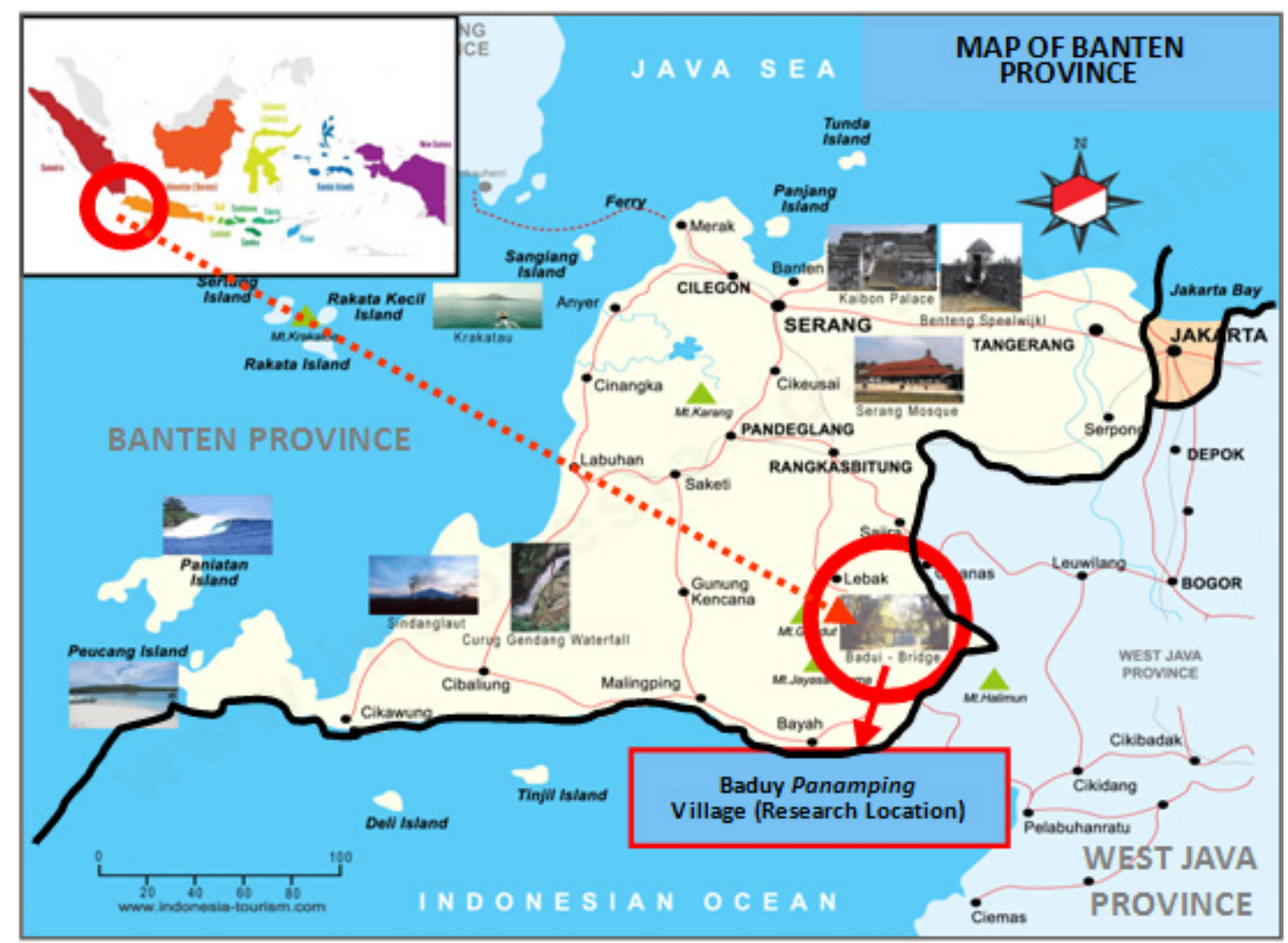

Source: Author adapted from Maftukha [11]

Figure 1. Map of research locations in Baduy Panamping village

\section{Imah Panggung Architecture}

The house in the rough level of Sundanese is called imah, which means a place to take refuge from various weather and disturbances. In the more refined Sundanese language house is called Bumi with the same meaning Nuryanto [6] explained, the Bumi does not only mean home but furthermore means the origin of a person. In this case, Bumi has the meaning of land as the origin of which humans were created from its essence. The Sundanese people who still adhere to their ancestral traditions strongly believe that the house is not only a physical dimension but also a metaphysical one that is closely related to the unseen. For them, the house has a "soul" just as humans have a spirit, so that in every process of building it is not arbitrary. Many rules must be observed so as not to cause problems [12]. The strength of the house is not only influenced by strong and sturdy structures, but there are non-physical factors that come from their ancestors [13].

The Sundanese traditional house is the imah panggung, as is the case in Baduy Panamping village. Imah panggung (see figs. 2 and 3 ) is a house that has an empty space under the floor (kolong). Kolong as a medium for air circulation can provide comfort in the house. This type of house is owned by a very strong community holding ancestral customs. Imah panggung in Baduy Panamping village entirely uses the roof of sulah nyanda according to ancestral rules. Sulah nyanda is a roof shape that resembles a pregnant woman leaning back. The material must be of natural origin, not fabricated because it is prohibited by custom (pamali). There is a prohibition against using tiles, bricks, and other materials that contain earth essence because they mean burying oneself alive. Cosmologically (see fig. 2), the imah panggung consists of three layers of the world: (1) Buana Nyungcung or $A m b u$ Luhur (upper world/sacred) where everything is purified; (2) Buana Panca Tengah or Ambu Tengah (middle world/neutral) where humans and other living things are; and (3) Buana Larang or Ambu Handap (underworld/profane) the place of spirits. 

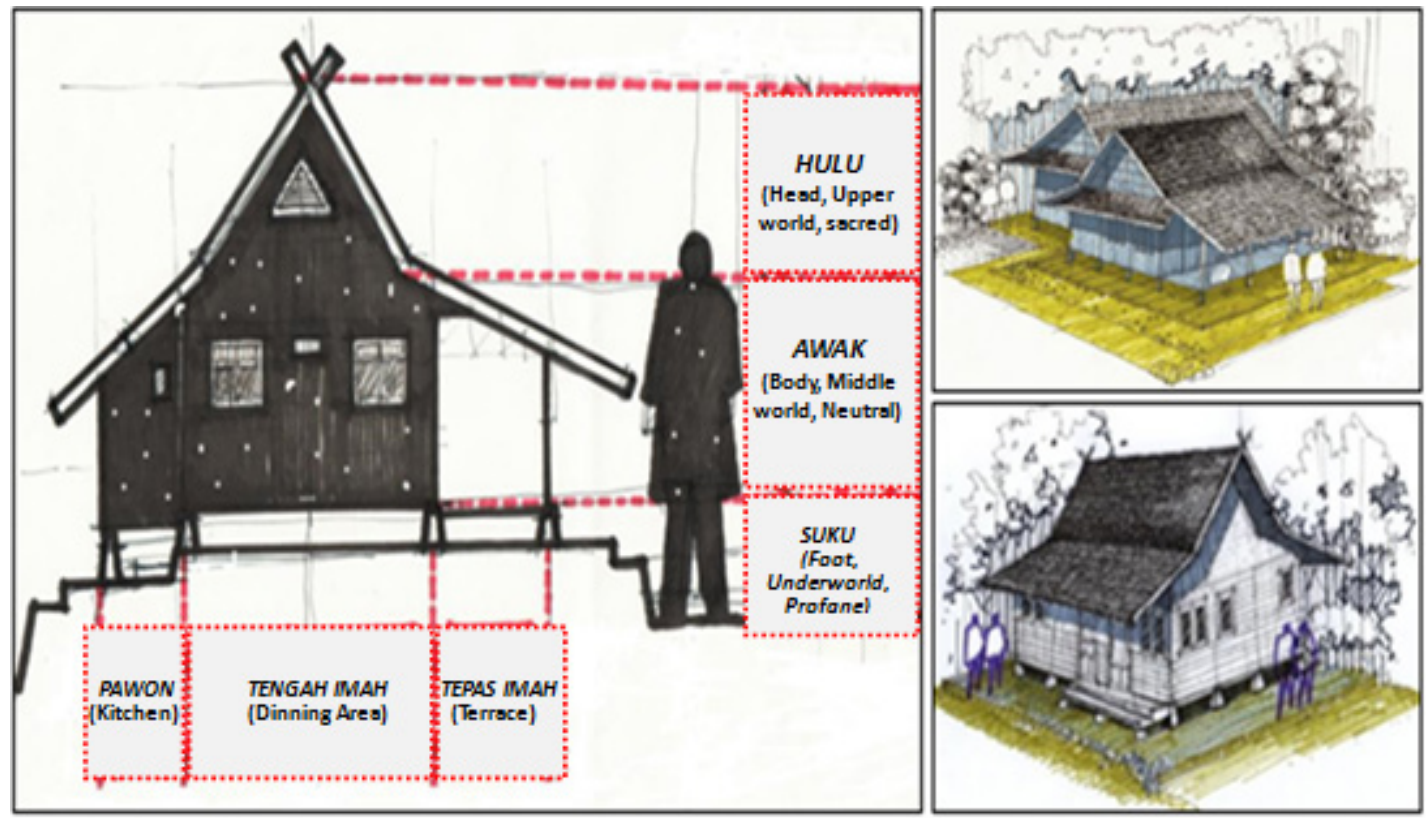

Source: Author, 2019

Figure 2. Cosmology in the imah panggung of Baduy community

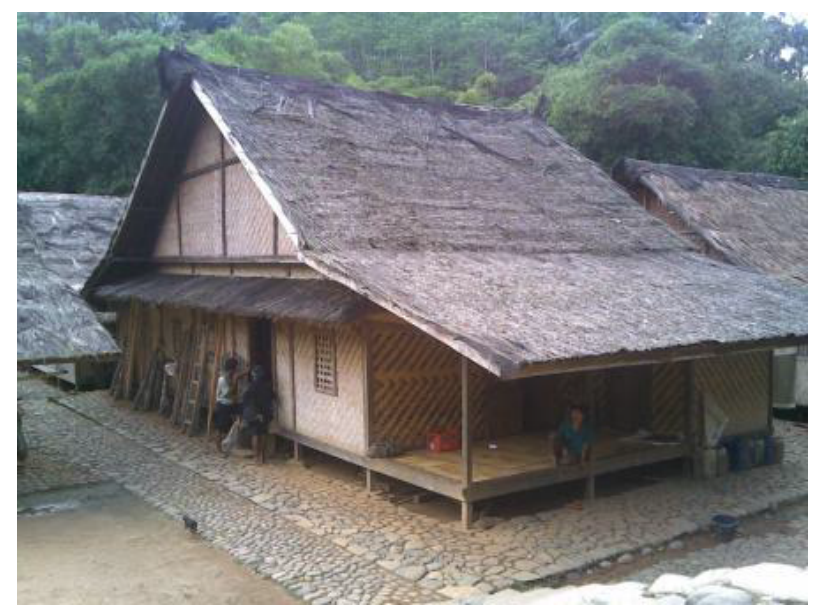

Source: Author, 2020

Figure 3. The form of imah panggung, Baduy Panamping village

\section{Characteristics of Structure, Construction, and Tectonic Elements of the Imah Panggung}

The characteristics of the structure and construction of the stage in the knowledge of the Baduy community are grouped into two parts: (1) Handap framework, namely the structure and substructure as the basis for the strength of the building including lelemah (ground surface) and umpak foundation; (2) Middle frame, namely structures and constructions whose position is in the middle of the body of the building as forming a house frame so that they can stand upright. This section consists of pangadeg (wall) and lantayan (floor); (3) The sublime frame is a structure and construction that is located at the top as a protection for all building components. This section includes suhunan (roof), palapon (ceiling), and para (place to store plant seeds). The whole process of making the rarangka is related to the rituals performed by the builders.

In the tectonic context, construction workers in Baduy village understand how to take, process, make and bring together building materials to look very beautiful. Tectonics relates to the building materials used, including articulating joints' completion concerning construction styles. The builders in Baduy Village have the concept of "pondok teu beunang diteukteuk, lojor teu beunang connected", meaning that if there are building materials (wood, bamboo, coconut tree trunks, etc.) that are very limited in size, they cannot be changed, but used improperly. Changing from the original form means changing nature, and it means breaking the rules of the ancestors. All building materials are obtained from natural surroundings through specific ritual processes. The method of cutting, cutting, and processing is meticulous not to cause disasters; for example, bamboo must be cut down in the month of the rainy season (around March) at dawn or the full moon so that pests are not disturbed [6][36].

The connection system on the stage of the Imah Rarangka is in pupurus (pen-holes) and adu manis (meeting or corner). These two connections are very popular with the Sundanese traditional community, not only in Kampung Baduy but in all other areas. According to the builders, the pupurus and adu manis connection has extreme binding power, because it is strengthened by paseuk (pegs) and fibers or rattan ties. Everything is done manually, not allowed to use modern equipment because it is prohibited by custom. According to them, such work processes have the meaning of maintaining a good relationship with nature. Building materials do not come 
into contact with modern equipment but through the touch of soft and affectionate human skin.

\section{Technical Elements of the Imah Panggung}

Havery [14] defines technique as a rational procedure so that interrelated components can become one unit. Poerwadarminta [15] technique is a method or system of doing something. Wikipedia Online states, technic or engineering is the application of science and technology to solve human problems. Based on the three definitions above, the keyword for technical elements is rational or logical (makes sense). The ability to think logically is the main provision of life for humans to be able to empower all abilities and solve the problems at hand [16]. Concerning logic, the technique is one of the thinking concepts that prioritizes reason, ratio, objectivity, is an empirical, factual, laboratory, and replicable [17]. Modern society highly upholds rationalism (ratio, reason) than empiricism (both physical and inner sensory experiences). Everything beyond the reach of the reason is called takhayul (superstition) or making up (lying).

Modern society plans and designs houses using the services of architects with sophisticated technological capabilities, prioritizing logic, high aesthetic taste, structural systems, construction, and fabricated materials. Meanwhile, the traditional community in Baduy Panamping village, on the other hand, was without an architect but by a local building expert called by tukang wangunan. With his instinctive sharpness and physical and inner sensory experience, tukang wangunan can carry out building techniques that are considered difficult by architects, for example the connection system without nails only uses paseuk (pegs), contour engineering through swales, ties using injuk ropes, and so on other.

The technique of installing the house foundation frame is entirely done manually without modern equipment. Umpak or tatapakan (see fig. 4) is the foundation it is made of rock or rock formed to resemble trapezium placed on the ground (lelemahan). On it are installed the main posts which are connected by beams (see fig. 5). Likewise, the conventional technique of installing floor and wall frames (see fig. 5). The connection technique for poles and beams uses paseuk, without nails, while for bamboo it uses fibers or rattan. Although it looks simple, it is so strong that the house can last a long time. Customary rules strictly prohibit the use of machine tools and fabricated materials, because they are considered against their ancestors. The whole work process is regulated and carried out by the tukang wangunan under the control and supervision of the Pu'un (customary leadership). If there are errors, both technical and non-technical, the tukang wangunan always coordinates with the Pu'un.

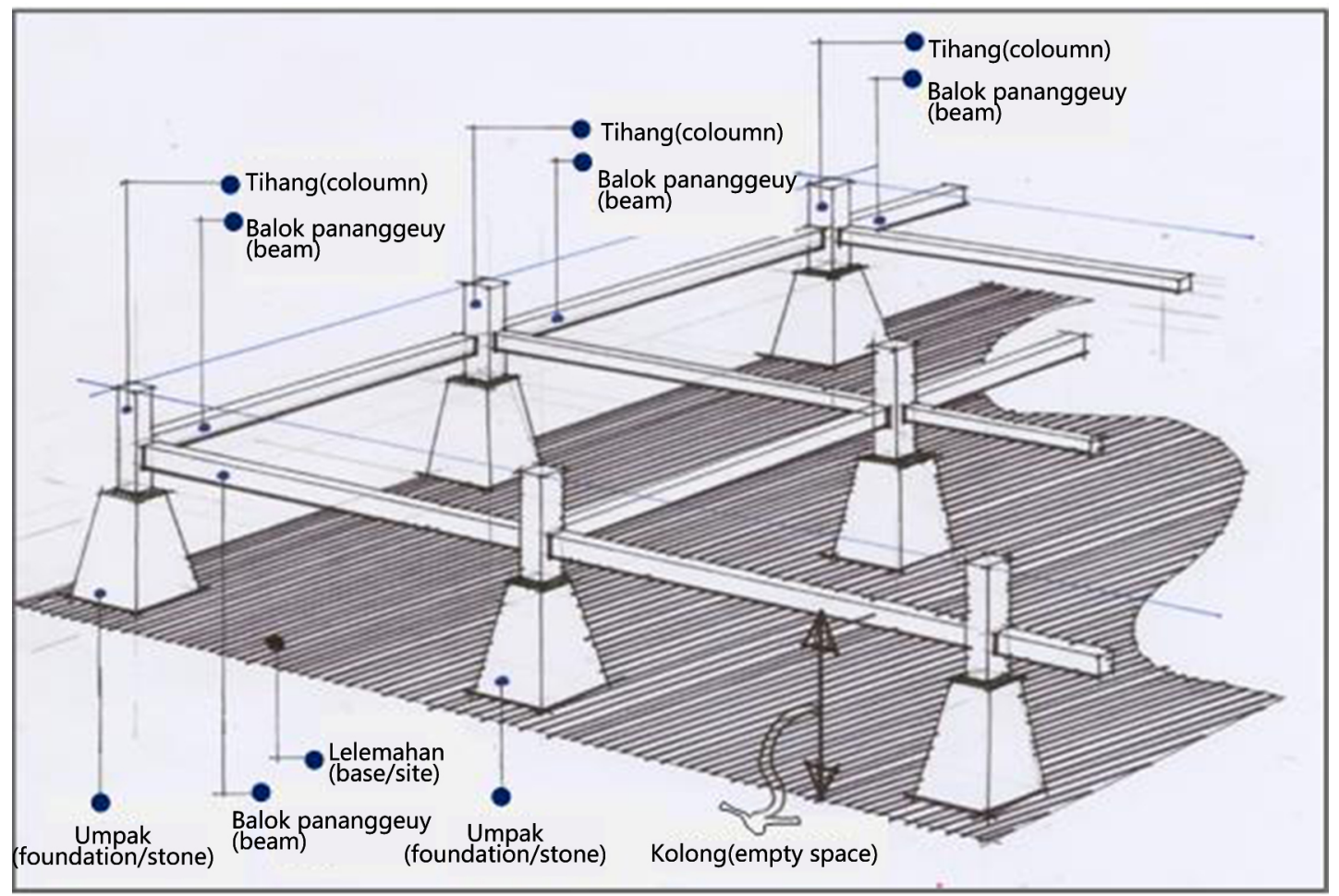

Source: Author, 2006

Figure 4. Umpak or tatapakan foundation installation technique 
The floors and walls are made of woven or chopped bamboo. The manufacturing technique is also done manually, without machines. The talupuh floor and the bilik awi walls are reinforced by palm fibers and clamped by bamboo strips (see fig. 5). In this case, tukang wangunan have a vital role and are required to think tactical and technical in every job. Logical thinking quickly without the help of modern tools will determine the success of building a house. In every task, tukang wangunan must not make mistakes, especially those related to customary rules, because they are very sacred. If something goes wrong at work, it must be reported to Pu'un immediately.

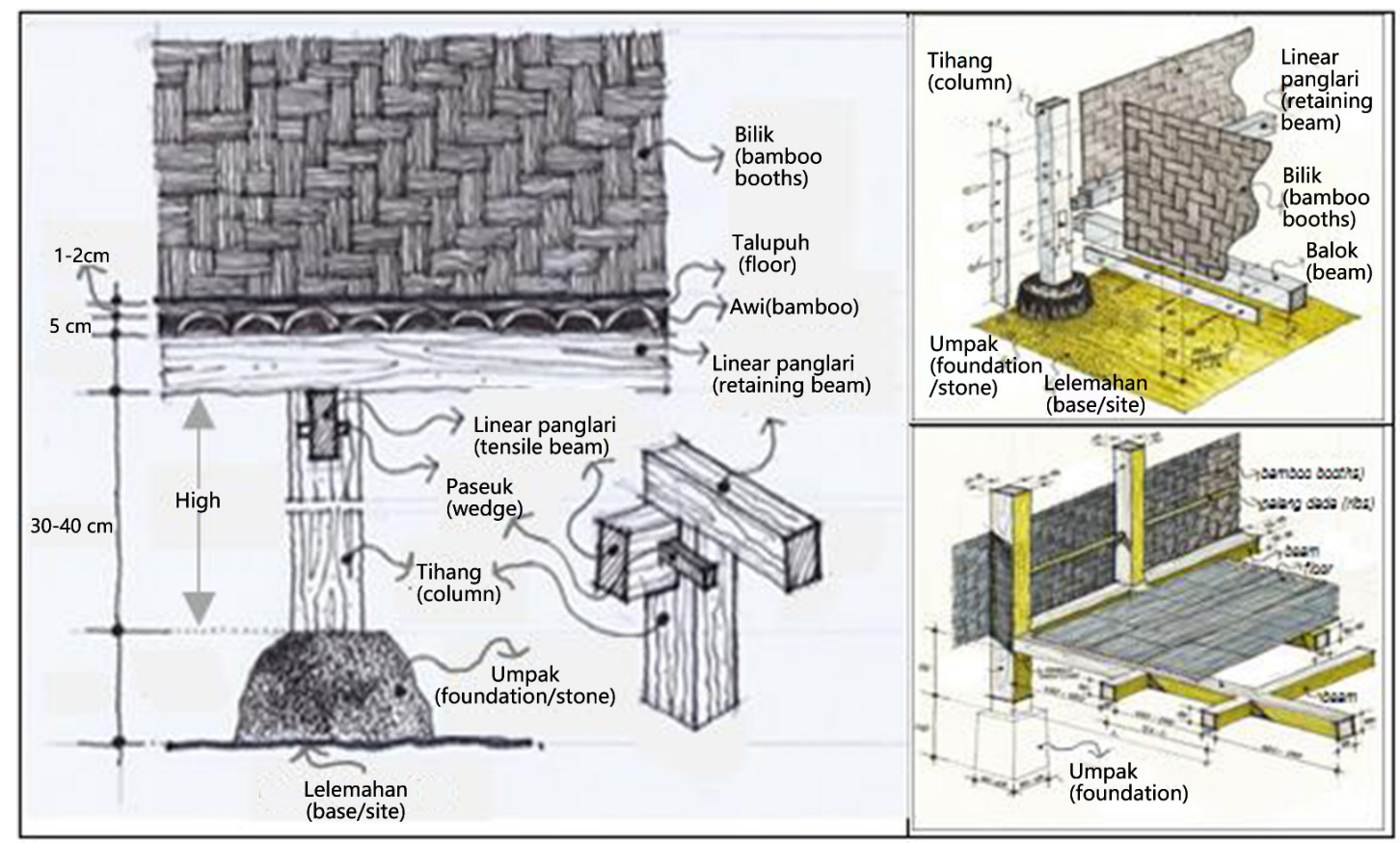

Source: Author, 2019

Figure 5. Roof, floor, and wall installation technique

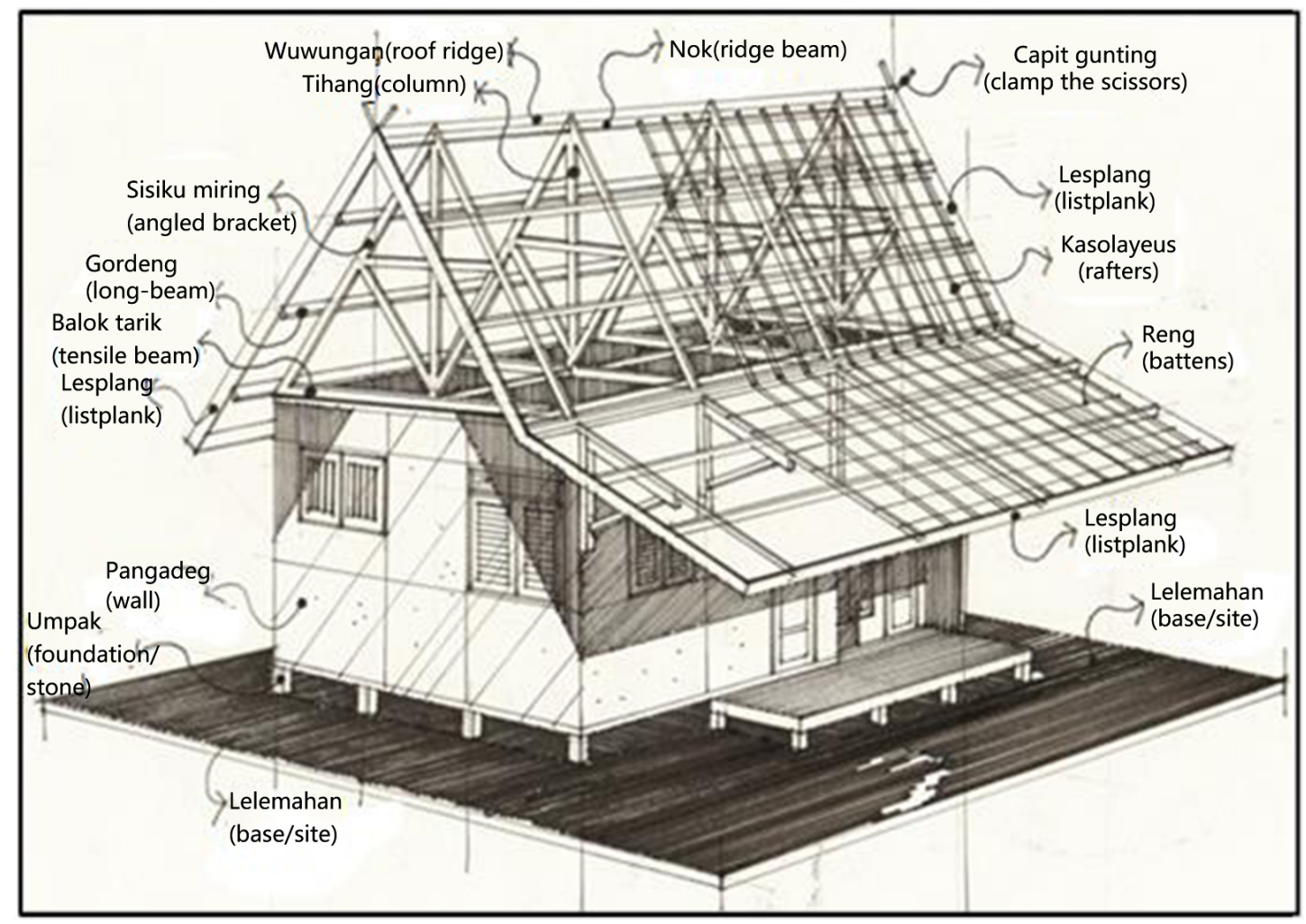

Source: Author, 2019

Figure 6. Truss on the roof (suhunan) installation technique 
The technique of installing the roof frame (suhunan) is the last part of the procession of building a house (see fig. 6). All work is also done manually. The tukang wangunan first assembles the posts and beams on the vacant land, then the roof frame is lifted and mounted on the top. The poles and beams are assembled using a strength system for the connection of pegs, clasps, and fibers or rattan ties. There were no nails or wires found in the joints, because of the taboo (pamali).

The connection technique in the structural system and house construction uses the pupurus type reinforced with paseuk (see fig. 7). Pupurus has been known by traditional communities, not only in Sundanese but throughout the archipelago (Indonesia). The terms used vary according to the local language. Besides pupurus, there is also another type of adu manis (angular connection), which is usually used in the "L" connection system, while pupurus is in the meeting connection or "T" connection. In the type of longitudinal connection or "I" using the type of coakan (klam). So that the position of the connection is strong, paseuk and fibers or rattan ties are used. There were no nails and wires in this section either. At the meeting connection, it is usually reinforced with a wooden wedge.

\section{Mystical Elements of the Imah Panggung}

Mysticism is still something scary and taboo because it deals with supernatural things. To speak mystical means to talk about the unseen in the form of a great mystery that is still dark, closed, hidden, sensitive, secret, which is invisible to the eye, and cannot be reached by logic. According to Ramdan [18], mysticism is a religious experience that can be introvertive (a person's tendency to emphasize more on the inner aspect) and extrovertive (a person's tendency to emphasize more on the outer aspects). Mystical experience is an attitude of mind, a tendency for the human soul to always seek and seek to gain experiences that are directly related to God [19]. Mystics are magical things that are not accessible to ordinary human minds [15]. Based on the above opinion, mysticism is the occult, outer experience, an inner way to uncover nonsense mysteries.

Mysticism in Baduy Panamping village is related to the procession of establishing the imah panggung which has two dimensions, namely social and ritual. The social dimension relates to fellow residents because building a house is a mutual cooperation activity. Meanwhile, the ritual dimension relates to mysticism to honor something or the purified essence. The Baduy Panamping community strongly believes that the rituals carried out will protect them from calamities. Maintaining good relations with the unseen means protecting the strength of the house from various bad possibilities.

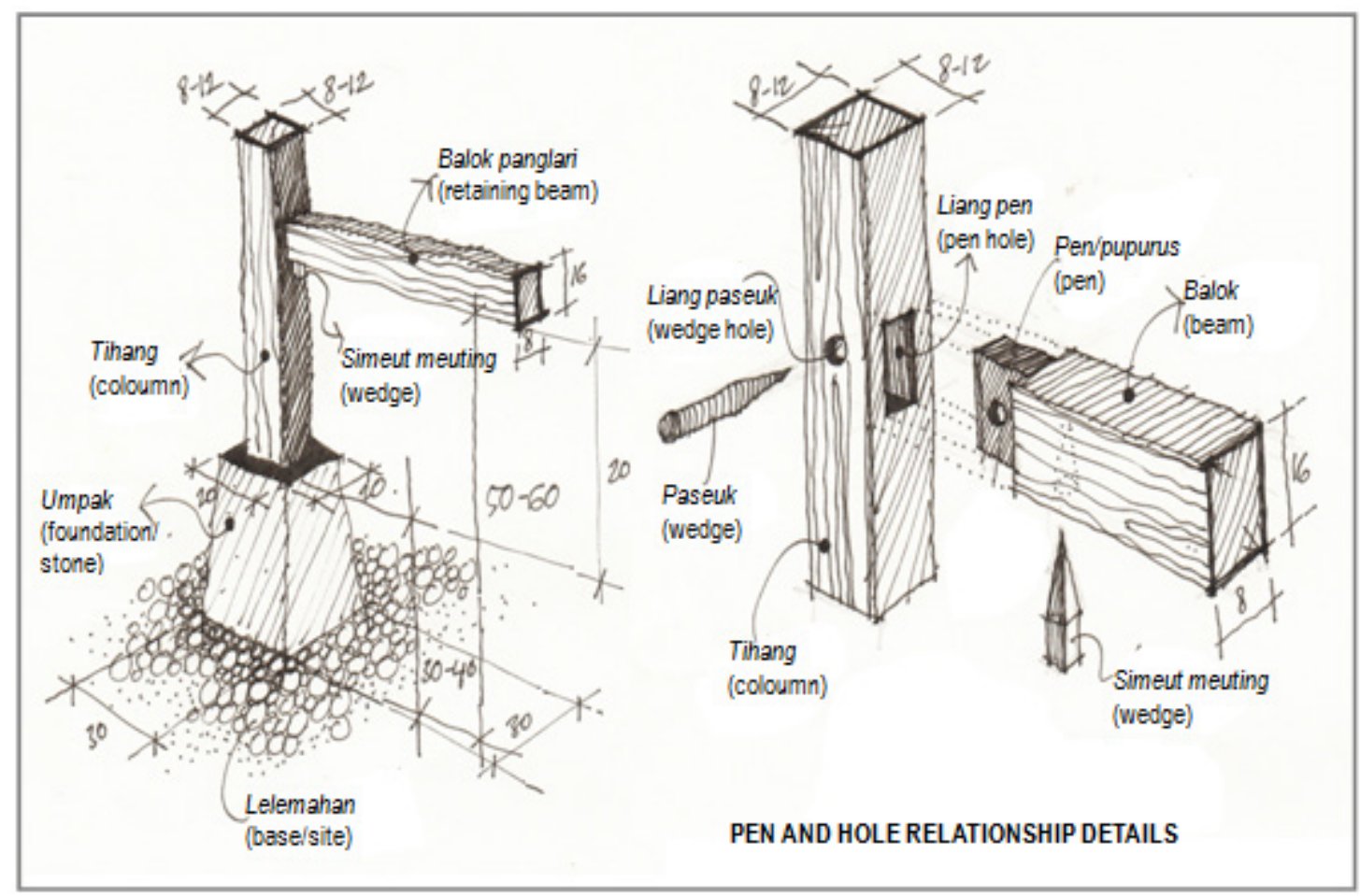

Source: Author, 2019

Figure 7. Technical joint on column and beam without nails 


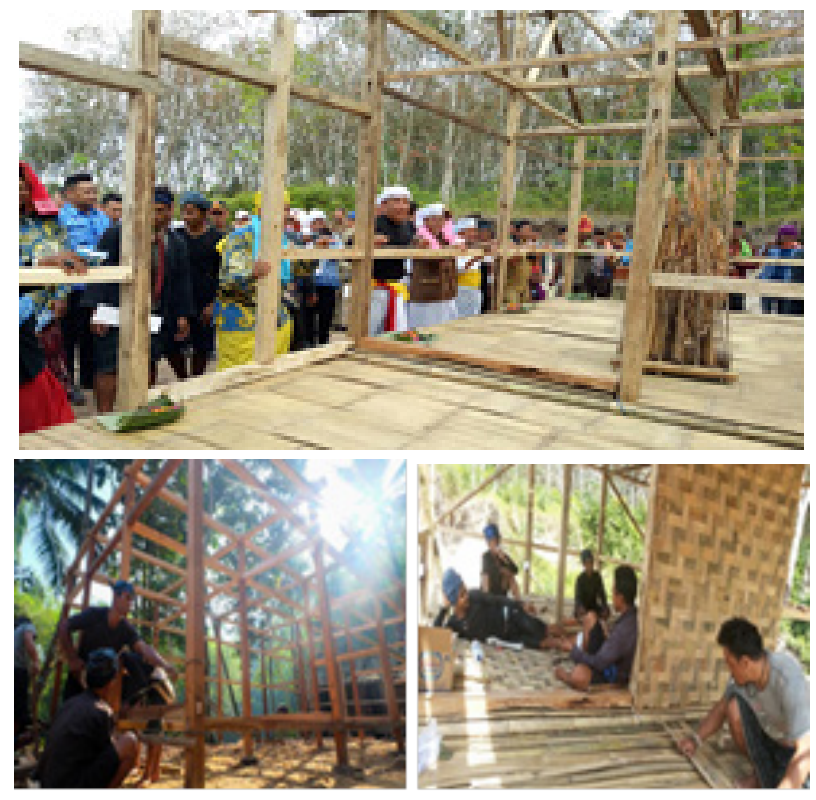

Source: Author, 2020

Figure 8. Imah panggung building process in Baduy Panamping

Mysticism is associated with ritual processions or sacred ceremonies of the people in Baduy Panamping village, especially in building their houses (see fig. 8). For them, building a house is a sacred event, because what is built is not only physical but also a spirit or soul. Building a house means building the soul of its inhabitants; The house and its inhabitants are the skin or cangkang, while the spirit (soul) of the inhabitants are the volume or eusi. In their thinking, cangkang and eusi are two things that complement each other, as a symbol of harmonization. Without eusi, the cangkang is meaningless, because it is empty, and without the cangkang, the eusi will not be maintained, because it is unprotected, so both of them need each other. A house without inhabitants, does not look alive, because there is no life; a body without a soul (spirit) will not live (die). When the house is filled with residents and a feeling of being happy (comfortable and peaceful) is created, that's when there is a harmonization which in the Baduy Panamping language is called repok ngajodo, which means suitable or harmonious.

The existence of a special room in the house in the form of a goah as a place to store rice is a mystical symbol that is closely related to the softness of Sanghyang Sri Pohaci (Rice Goddess) who is considered by the Baduy Panamping community as the "Giver of life". At certain times offerings are provided in the cave as a tribute to the Rice Goddess (Dewi Padi or Dewi Sri) so that the harvest is always abundant. In the village, there are also open spaces wide enough to carry out various rituals, such as kawalu and seren taun (Thanksgiving Day). The mystical atmosphere is felt at the time of the ritual because not only the public but also other unawares were present.

The process of building a house in Baduy Panamping village was carried out jointly (see fig. 8). All residents help unconditionally, according to their respective abilities. Especially for the ritual procession of building a house (ngadegkeun imah), there are three stages, namely: (1) Ancer-ancer, namely the preparation stage; (2) Ngadegkeun or nangtungkeun, namely the implementation stage; (3) Ngaruwat is the final stage of the whole process, in the form of a welcome to fill a new house. The mystical atmosphere during the practice of the ngadegkeun imah ritual is very pronounced because many jangjawokan, jampe, and ubarampe (prayers) recited by the tukang wangunan and $P u^{\prime} u n$ always accompany the ritual implementation. The Baduy Panamping community believes that every place and material they take is controlled by supernatural beings, so they must ask permission from those waiting for them.

\section{Symbolic Elements of Stage Imah Architecture}

The symbolic element in question is how the Baduy people interpret the symbols that exist in their houses' architecture. The symbolic element is closely related to form because, in Baduy society, the form is used as a parable full of hidden, symbolic meanings (siloka). The symbol is one of the human tools to reach knowledge and experience beyond the boundaries of culture. The orientation of symbols is transcendent knowledge, thoughts, and experiences, which transcend human beings' inherent boundaries. Humans cannot enter the transcendent realm with their limitations. To reach that realm, humans are forced to use analogies; humans play with metaphors. Analogy and metaphor transform inherent knowledge and experience, thus connecting with the transcendent [6].

The symbolic manifestation of the Baduy community's architecture can be seen in the house plan, which has a rectangular base, which is called opat interpreter or ngajuru opat, which means the same four corners. Opat interpreter is related to the understanding of the four cardinal directions, namely kidul (south), kaler (north), kulon (west), wetan (east) plus one in the middle as puseur (center). Kidul or south is a direction that has sacred value because as the place of Lalayang Sasaka Domas (the holy place of Baduy people), the entire face of the building must face the kidul be on the kidul-kaler axis. To determine good or bad days, they recognize the terms weton: legi, pahing, pon, kliwon, and wage. In the birth cycle of the Sundanese people, there is also the term weton or babar, which is the day of birth which is often used as a benchmark for measurement and calculation in building a house, usually the husband's weton is used, because he is the head of the family. Weton is used for the width and height of the door and the height of the building walls. The basic rectangular shape on the house plan relates to human origins from four elements, namely: taneuh or land as a symbol of human origin, cai or water as a symbol of human's primary needs, seuneu or fire as a symbol of lust, and wind or air as a symbol of life and 
human life. Thus, symbols are an inseparable part of the Baduy community: "breathe pinuh ku siloka, manusa jeung siloka keur nu kawasa", meaning that life is full of symbols. Therefore humans with symbols are one unit to serve Sanghyang Keresa (God). From this sentence, it is obvious that the Baduy community cannot be separated from symbols because symbols become media in relationships and maintain harmony with God.

\section{Tukang Wangunan as a "local architect"}

The Baduy tribe community in general does not know the terms architect, planner, or designer. They are more familiar with tukang wangunan to call them building experts (see fig. 9). In fact, the principle between tukang wangunan and architects has the same task, namely, to realize the desire of the homeowner to have a new house. In the view of the Baduy tribe community, tukang wangunan are people who are able to establish magical communication with ancestors and spirits.

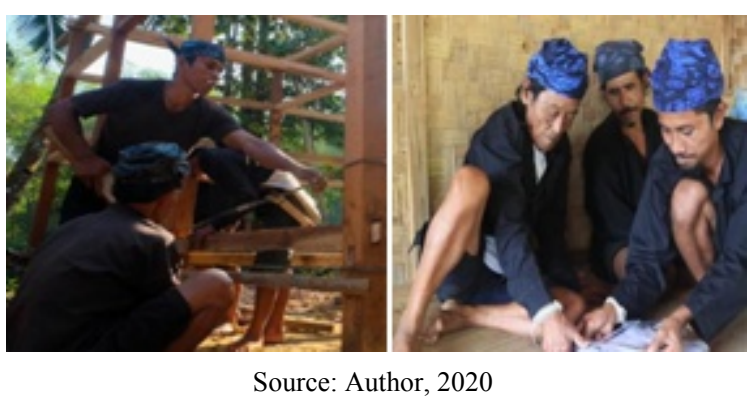

Figure 9. Tukang wangunan in Baduy Panamping village

This ability is not owned by others, including architects who are only able to communicate with clients and drawings. Therefore, the work carried out by tukang wangunan is a tough task, because it bridges two interests, namely the prospective house owner (lahiriyah/in the soul) with the ancestors/spirits (batiniyah/beyond the soul). If the two communications are well established, the process of building a house will run smoothly. But if it is the other way around it will get into trouble.

The expertise of the tukang wangunan in Baduy Panamping village is based on their loyalty to the custom of tatali paranti karuhun (ancestral tradition rules). Experience and sharp instincts that have been trained become a strong foundation in every job (see fig. 9). There is no modern equipment used, it entirely relies on hand skills (hand made), pikiran/pikir (mind), perasaan/rasa (feel), and anggota badan (body). Customary rules prohibit the use of manufactured machines and materials in buildings so that everything is done completely conventional. They are used to limitations, but never become obstacles. Besides, the procession of building a house in Baduy Panamping village is a collective work, because it is not only the tukang wangunan who work, but all residents voluntarily help according to their respective abilities.

Based on the structure of the customary organization, the position of the tukang wangunan in Baduy Panamping village was directly under $P u^{\prime} u n^{\prime}$ s leadership. In his craftsmanship practice, the task of tukang wangunan is not only to make an imah (house), but also leuit (rice storage), saung lisung (a place to pound rice), bale adat (traditional hall), including infrastructure, such as roads, ditches, water showers, and others. Pu'un as the customary leader has full authority to grant permits and cancel the plans of its residents to build houses based on certain considerations. In terms of ability, the tukang wangunan have different fields, for example, tukang awi (expertise about bamboo), tukang kayu (carpenters), and tukang batu (masons), some are even experts in all three. Their working principle is "teu maksa jeung teu dipaksa", meaning voluntary, not asking for payment or wages: "nulung ka nu butuh, nalang ka nu susah", which means helping those in need. Construction work is social, and they were commissioned by $P u^{\prime} u n$ at the request of their citizens. His skills and abilities are rare because not everyone meets the requirements to become a tukang wangunan.

\section{Manifestation and Harmonization}

Imah panggung in Baduy Panamping village is not only seen as a physical building but has a soul that cannot be separated from its inhabitants. In the view of society, imah is cangkang (shell/wrap/skin), while the soul is considered as eusi (core). The cangkang is concrete, the soul or spirit is abstract, while the householder is the real owner of the cangkang and eusi. The three manifestations result in a comfortable house arrangement to live in, because between cangkang, eusi, and its owner can harmoniously meet.

Furthermore, cangkang is technical, because it consists of the whole process of building a house physically, while eusi is mystical because the soul or spirit is present at the invitation of the ritual procession. The tukang wangunan in Baduy Panamping village were able to bring together, combine, and harmonize the two. This meeting resulted in a very beautiful combination with established communication, both technical and non-technical. Technical relates to the strength of structure-construction, while non-technical deals with things beyond human capabilities.

The architecture of imah panggung, which is widely spread in the traditional villages of the Sundanese people in Indonesia, can adapt to natural disasters, such as earthquakes, landslides, and floods. This is evidence of other strengths besides technicality. When an earthquake occurs, their house is safe and they continue their activities as usual. Some examples of traditional villages that have been hit by an earthquake include: Naga village in Tasikmalaya Regency was shaken by an earthquake with a magnitude of 10 SR in 2009, Baduy village in Lebak Regency was shaken by a 6.1 magnitude earthquake in 2018, Dukuh village and Pulo in Garut Regency was rocked by an earthquake 7.3 SR in 2009 , 
and other areas. Based on this incident, not a single house was damaged. Imah panggung their remains safe and solid. Even in Naga village, when the earthquake occurred, the people ran into the house, while in urban areas it was the opposite.

\section{Discussion}

Mysticism for the Baduy Panamping community is still very sacred to talk about, especially regarding their ancestors: "teu wasa bisi kabendon", meaning that we do not have the courage for fear of getting the wrath of our ancestors. The syncretic and mystical practices in the village of Baduy Panamping are still clearly inherent in the lives of the people. This is intended to maintain the balance of the universe. The magical-mystical balance is maintained by traditional ceremonies, while the social balance is maintained through mutual giving and mutual cooperation.

This discussion focuses on three things: (1) Techniques to build of imah panggung; (2) The mystique that accompanies the building technique; and (3) The ability of the tukang wangunan to match and combine techniques with mysticism. The technique of building of imah panggung can be seen in the foundation using umpak or tatapakan, the walls using bilik from bamboo and wooden, the floor is made of talupuh, the roof is made of injuk and hateup, its strength uses pupurus, paseuk, and tali, as well as differences in contours using swales and gawirs. This is confirmed by Harapan [20], that umpak is one of the techniques for making foundations in Sundanese traditional houses, including the use of other local materials. Local materials are very suitable for use as a medium for natural and environmentally friendly climatic adaptation [21]. In addition, the local wisdom of the community by managing houses based on the sengkedan system shows a solution to thinking as a form of land engineering [22][35].

Mystical images can be seen in the implementation of traditional rituals during the building process. The tukang wangunan in Baduy Panamping village has a mystical position higher than technique because it is related to supernatural powers which, if wrong, is difficult to repair. This differs from the error in the technique which can still be tolerated because it is technical. Mistakes in traditional rituals will have a negative impact on the house and its occupants so that the community does not dare to violate the law or pamali [23][36]. A harsher threat to violation of ancestral customs is in the form of two choices "hirup atawa paeh", meaning life (misery) or death, as in the Kasepuhan Ciptagelar and Baduy villages [24]. As a social sanction, those who violate are excluded from the environment of the original village and their status is no longer the indigenous people [25][34].

The ability of tukang wangunan to reconcile techniques with mysticism is critical to the success of the process of building a house. According to some of them, they explain that their abilities are based on instincts, habits, and experiences inherited from their predecessors: "neuleukeun, nuturkeun, migawe", which means starting from paying attention, following, and practicing. The essence of these three words is sincerity: "boga kadaek jeung daekan, kudu jeung hate lain ku jempe", the meaning is to want to do and have a will, must be imbued, truly, not by being silent.

According to them, bringing together technique and mystique must be careful and considerate outside of logic, for example the technique of installing a umpak stone as the foundation of a house without any additions. In order for the position of the umpak to be solid and stable, according to mystics, it must be doused with the blood of a rooster whose feathers are black with incantations. The goal is to ask permission from the spirits who control the stone so that the entire structure of the house is safe. Another way is through tirakat and wangsit which he receives through dreams, for example the technique of installing the tihang adeg, then the congo position (base) must be below with a certain type of wood. In order for the wood to be durable and in a stable position, according to mystics, when it is cut down, offerings and incantations must be given to the wood guard. Another example is, when installing a truss for the roof, and offering called parawanten. The offerings consist of bananas (one bunch), sugar cane (one segment), rice (one small bunch), and others. The purpose of this offering is to ask God and the ancestors for salvation so that the process of building a house runs smoothly.

\section{Conclusions}

This conclusion is the final note of the entire research process which includes three important points: (1) The Baduy tribe community, especially Baduy Panamping views mystical elements ( пи teu kadeuleu) as occupying a higher position than techniques, because of their relationship with karuhun (ancestral permission/blessing); "mun teu dibere ijin ku karuhun, imah moal nangtung", meaning that if there is no blessing from the ancestors, the house will not stand firmly; (2) In the technical element ( $n u$ kadeuleu) there is a core of strength as a knot point in the form of jangjawokan (mantra/jampi/ubarampe) which is always recited by the tukang wangunan so that it sticks firmly to every dimension of the material; "kuat imah lain ku kai, lain ku awi, tapi menta ka nu nyicingan kai jeung $a w i "$, meaning that the strength of the house is not due to the material, but because it asks the power of those who control every kind of material; (3) The meeting point between technical and mystical lies in the belief system of the Baduy Panamping community, namely Sunda Wiwitan, which gave birth to a cosmological view of the universe; 
Buana Nyungcung or Ambu Luhur (upper world), Buana Panca Tengah or Ambu Tengah (middle world), and Buana Larang or Ambu Handap (underworld). The upper and lower world represents the mystical element, because it is invisible to the eye, while the middle world is the embodiment of the technical element because it relates to the physical, such as humans, place of residence, material, technology, innovation, engineering, creativity, and others.

These three things are able to be brought together by tukang wangunan in building a house to produce harmonious architectural work. They work not only with mind and energy but with a very measured heart and instinctual acuity, being able to see other abstract dimensions and communicate them well.

\section{Acknowledgments}

The author expresses his deepest gratitude to various parties who have contributed to this research, such as Pu'un, tukang wangunan, kokolot, respondents, informants, and residents of Baduy Panamping village; Promoter, Co-Promoter 1 and 2, examiners of the Dissertation Qualification Examination; Governors, Regents, Camat, and Lurahs in administrative research locations; University Leaders, Deans, and Coordinator of the Doctoral Engineering Science Program Study, Udayana University, Bali. It would be in vain without their help until this research finds the answer and its meaning.

\section{REFERENCES}

[1] Koentjaraningrat, Pengantar Ilmu Antropologi, 2 ed. Jakarta: PT Rineka Cipta, 2015.

[2] K. Adimihardja, A. Kartiwa and G. Undang, Eds. Berkarya di Belantara Budaya: Dinamika Budaya Lokal, Partisipasi, dan Pembangunan, Pertama ed. Bandung, Indonesia: Indra Prahasta, Bandung, 2015.

[3] S. A. Paturusi, " Segregasi Ruang Sosial Antara Pendatang dengan Penduduk Asli pada Permukiman Perkotaan di Denpasar," (in Indonesia), Jurnal Kajian Bali, Arsitektur vol. 06, no. 02, pp. 57-78, 2016.

[4] N. K. A. Dwijendra, "Eco Tourism Opsi Pengembangan Pariwisata Berkelanjutan di Wilayah Bali Tengah," in SENADA: Seminar Nasional Desain dan Arsitektur Sekolah Tinggi Desain Bali, 2018, vol. 1, no. 2, pp. 11-27, Bali, Indonesia: STD Bali Press, 2018.

[5] I. M. Adhika and N. K. A. Dwijendra, "Selfie Photos Area and Its Implication to Water Availability and Social Culture in Wanagiri Village, Bali Indonesia," (in English), International Journal of Psychosocial Rehabilitation, Article vol. 24, no. 04, pp. 5573-5578, 2020.

[6] Nuryanto, "Patukangan Wangunan pada Kampung Baduy
Tangtu di Kabupaten Lebak Provinsi Banten," S3-Doktor Draft Proposal Disertasi (Bahan Ujian Proposal), Program Studi Doktor Ilmu Teknik, Universitas Udayana, Bali-Indonesia, Bali, Indonesia, 2020.

[7] K. D. Bailey, Methods of Social Research, Fourteth Edition ed. New York: A Division of Macmillan Publishing Co. Inc., New York., 1994.

[8] W. L. Neuman, J. Lasser and E. Adams, Eds. Basic of Social Research Methods: Qualitative and Quantitative Approaches, Second Edition ed. Boston: Allyn and Bacon Co., Boston, 2004.

[9] J. P. Spradley, C. A. Belmont, Ed. Participant Observation Revised Edition ed. United States: Cengage Learning, Inc., United States, 1980.

[10] J. Ziesel, I. Altman and D. Stokols, Eds. Inquiry by Design: Tools for Environment-Behaviour Research, First Edition ed. California: Cambridge University Press, California, 1978.

[11] N. Maftukha, "Visualisasi Motif Tenun Hasil Anak Usia Dini di Suku Baduy Luar," (in Indonesia), NARADA: Jurnal Desain \& Seni, Desain Produk vol. 6, no. 2, pp. 273-290, 2019.

[12] A. Harapan, "Sistem Bangunan Rumah Tradisional di Kampung Adat Baduy Luar Kadu Ketug, Kabupaten Lebak, Banten," (in Indonesia), KORIDOR: Jurnal Arsitektur dan Perkotaan, vol. 10, no. 01, 20192019.

[13] I. Hermawan, "Bangunan Tradisional Kampung Naga: Bentuk Kearifan Warisan Leluhur Masyarakat Sunda," Sosio-Didaktika: Social Science Education Journal, vol. 1, no. 2, pp. 141-150, 20142014.

[14] J. L. Havery, "Information Systems: Theory and Practice," ed: Yourdon Press. Prentice Hall, 2009.

[15] W. J. S. Poerwadarminta, "Kamus Besar Bahasa Indonesia," in Kamus Besar Bahasa Indonesia, 3 ed. Jakarta, Indonesia: Balai Pustaka, Indonesia, 1991.

[16] M. Z. Wahyudi, "Masyarakat tak Terbiasa Berpikir Rasional," in KOMPAS.com, ed. Jakarta, Indonesia: KOMPAS, 2013.

[17] A. Habib, "Ilmu Teknik secara Epistemologi," in Ilmu adalah hikmah yang tercecer, carilah dan milikilah, meskipun jauh dan menjenuhkan vol. 2011, ed. Yogyakarta, Indonesia: Blogspot.com, 2011.

[18] Ramdan, Mistisisme, Pertama ed. Yogyakarta, Indonesia: LESFI, Yogyakarta, 1990.

[19] M. Smith, R. Woods, Ed. The Nature and Meaning of Misticism, First Edition ed. London, UK: The Athlone Press, University of London, UK, 1980.

[20] A. Harapan, "Sistem Sambungan Konstruksi Rumah Tradisional di Kampung Pulo, Jawa Barat," (in Indonesia), Jurnal Arsitektur ARCADE, vol. 2, no. 2, pp. 101-107, 2018.

[21] M. Gartiwa, "Modus Adaptasi Klimatik pada Arsitektur Vernakular Masyarakat Kampung Cikeusik Desa Kanekes Kabupaten Lebak Provinsi Banten," S3-Doktor Disertasi, Arsitektur Universitas Langlangbuana, Bandung, Institut Teknologi Bandung, Indonesia, Bandung, Indonesia, 2017.

[22] I. Hermawan, "Sengkedan: Bentuk Rekayasa Lingkungan 
untuk Permukiman dan Pertanian," (in Indonesia), Jurnal PATANJALA, vol. 7, no. 2, pp. 201-216, 2015.

[23] N. Rusnandar, Ungkapan Tradisional yang Mengandung Nilai Moral dan Nilai Tabu atau Magis di Masyarakat Kampung Kuta Kabupaten Ciamis dan Kampung-kampung adat Kabupaten Tasikmalaya di Jawa Barat, Pertama ed. Bandung: Balai Kajian Sejarah dan Nilai Tradisional, Bandung, 1992.

[24] Nuryanto, A. Holid, Ed. Arsitektur Nusantara: Pengantar Pemahaman Arsitektur Tradisional di Indonesia, Pertama ed. Bandung: PT. Remaja Rosdakarya, Bandung, 2019.

[25] N. Rusnandar, "Seba: Puncak Ritual Masyarakat Baduy di Kabupaten Lebak Provinsi Banten," (in Indonesia), Jurnal PATANJALA, Arsitektur vol. 5, no. 1, pp. 82-98, 2015.

[26] N. P. S. Nurjani, N. K. A. Dwijendra, How Traditional Balinese Houses Can Adjust and Cater for International Tourist in the Canggu Area, Bali Indonesia? In: International Journal of Psychosocial Rehabilitation, Vol. 24, No. 03, DOI: 10.37200/IJPR/V24I3/PR201901, 2020.

[27] Ngakan Ketut Acwin Dwijendra. (2020). From Tradition to Modernization in Morphological Process of Indigenous Settlement Patterns in Bali, Indonesia. International Journal of Advanced Science and Technology, 29(8s), 172 - 184. Retrieved from http://sersc.org/journals/index.php/IJAST/ar ticle/view/1043.

[28] M. V. Yogantari, N. K. A. Dwijendra, Visual Exploration Using Acrylic Paint on Used Fashion Items for Sustainable Use. In: International Journal of Psychosocial Rehabilitation, Vol. 24, No. 03, DOI: 10.37200/IJPR/V24I3/PR201902, 2020 .

[29] Ngakan Ketut Acwin Dwijendra. I Putu Gede Suyoga (2020). Analyze of Symbolic Violence Practices in Balinese Vernacular Architecture, Bali Indonesia. International Journal of Innovation, Creativity and Change, Vol. 13, Issue 5, 18 June 2020. Retrieved from https://www.ijicc.net/imag es/vol_13/Iss_5/13543_Dwijendra_2020_E_R.pdf.

[30] Wa Ode Sifatu, Herman Sjahruddin, Yana Fajriah, Ngakan Ketut Acwin Dwijendra, Adi Santoso. "Innovative Work Behaviors In Pharmacies Of Indonesia: Role Of Employee
Voice, Generational Diversity Management and Employee Engagement", SRP, 11(2), 725-734. 2020, DOI:10.31838/srp.2020.2.105.

[31] N. K. A. Dwijendra, Identity Struggle Perspective in Car-Shaped Shrine in Paluang Temple, Nusa Penida Bali, Indonesia, International Journal of Psychosocial Rehabilitation, Vol. 24, No. 4, DOI: 10.37200/IJPR/V24I4/ PR201653, 2020.

[32] Ngakan Ketut Acwin Dwijendra (2020). Meru as a Hindu Sacred Building Architecture with a High Roof and Resistant to Earthquakes in Bali, Indonesia. Civil Engineering and Architecture, Vol. 8 (3), pp. 350 - 358. DOI: 10.13189/cea.2020.080319. Retrieved from http://www.hrp ub.org/journals/article info.php?aid=9473.

[33] I Nyoman Widya Paramadhyaksa, Ngakan Ketut Acwin Dwijendra, Ni Ketut Pande Dewi Jayanti, I Kadek Merta Wijaya (2020), Orientation on Spatial Planning in Pinggan Village, Kintamani District, Bangli Regency, Bali, Indonesia. Solid State Technology Volume: 63 Issue: 6 Publication Year: 2020.

[34] Ngakan Ketut Acwin Dwijendra, Frysa Wiriantari, Desak Made Sukma Widiyani, Anak Agung Ayu Sri Ratih Yulianasari, Arya Bagus Mahadwijati Wijaatmaja. (2020). Transformation of Catuspatha in Bali Indonesia: Alteration Ideas from Empty Space to Aesthetic Element of City. Rupkatha Journal on Interdisciplinary Studies in Humanities. Volume 12, Number 6, 2020. DOI: 10.21659/rupkatha.v12n 6.15 .

[35] Ngakan Ketut Acwin Dwijendra, Akhmad Anwar Dani, Dian Wardiana Sjuchro, Elena N. Klochko, Yenni Patriani (2020), Political And Social Infrastructure Towards High Quality Tourism Sites. European Journal of Molecular \& Clinical Medicine, 2020, Volume 7, Issue 11, Pages 1764-1773.

[36] Siluh Putu Natha Primadewi, Ngakan Putu Sueca, Ngakan Ketut Acwin Dwijendra , Ni Ketut Ayu Siwalatri, "Emerging Architect's Design Method in Designing Tourist Accommodation Case Study: Tourist Accommodation in Ubud, Bali," Civil Engineering and Architecture, Vol. 9, No. 2, pp. 271 - 280, 2021. DOI: 10.13189/cea.2021.090201. 